Research Division

Federal Reserve Bank of St. Louis

Working Paper Series

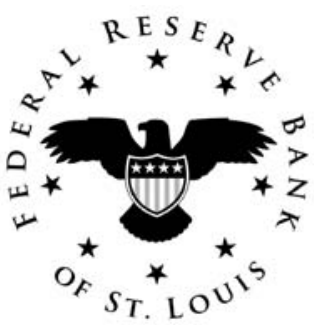

\title{
The Promise and Performance of the Federal Reserve as Lender of Last Resort 1914-1933
}

\author{
Michael D. Bordo \\ and \\ David C. Wheelock
}

Working Paper 2010-036B

http://research.stlouisfed.org/wp/2010/2010-036.pdf

October 2010

Revised January 2011

FEDERAL RESERVE BANK OF ST. LOUIS

Research Division

P.O. Box 442

St. Louis, MO 63166

The views expressed are those of the individual authors and do not necessarily reflect official positions of the Federal Reserve Bank of St. Louis, the Federal Reserve System, or the Board of Governors.

Federal Reserve Bank of St. Louis Working Papers are preliminary materials circulated to stimulate discussion and critical comment. References in publications to Federal Reserve Bank of St. Louis Working Papers (other than an acknowledgment that the writer has had access to unpublished material) should be cleared with the author or authors. 


\title{
The Promise and Performance of the Federal Reserve as Lender of Last Resort 1914-1933
}

\author{
Michael D. Bordo \\ Rutgers University and NBER \\ Bordo@econ.rutgers.edu \\ David C. Wheelock \\ Federal Reserve Bank of St. Louis \\ Wheelock@stls.frb.org
}

This paper examines the origins and early performance of the Federal Reserve as lender of last resort. The Fed was established to overcome the problems of the National Banking era, in particular an "inelastic" currency and the absence of an effective lender of last resort. As conceived by Paul Warburg and Nelson Aldrich at Jekyll Island in 1910, the Fed's discount window and bankers acceptance-purchase facilities were expected to solve the problems that had caused banking panics in the National Banking era. Banking panics returned with a vengeance in the 1930s, however, and we examine why the Fed failed to live up to the promise of its founders. Although many factors contributed to the Fed's failures, we argue that the failure of the Federal Reserve Act to faithfully recreate the conditions that had enabled European central banks to perform effectively as lenders of last resort, or to reform the inherently unstable U.S. banking system, were crucial. The Fed's failures led to numerous reforms in the mid-1930s, including expansion of the Fed's lending authority and changes in the System's structure, as well as changes that made the U.S. banking system less prone to banking panics. Finally, we consider lessons about the design of lender of last resort policies that might be drawn from the Fed's early history.

Keywords: Federal Reserve Act, lender of last resort, discount window, banking panics, Great Depression

JEL classification codes: E58, G28, N21, N22

Prepared for the Federal Reserve Bank of Atlanta Conference Commemorating the $100^{\text {th }}$ Anniversary of the Jekyll Island Conference, Jekyll Island, Georgia, November 5-6, 2010. The authors thank Will Roberds, Ellis Tallman, and Eugene White for comments on a previous version of this paper. Views expressed in this paper are not necessarily official positions of the Federal Reserve Bank of St. Louis or the Federal Reserve System. 
$\underline{\text { Introduction }}$

The actions by the Federal Reserve to defuse the financial crisis of 2007-08 renewed long-standing debates about how central banks should act as lenders of last resort. The Fed's defenders contend that the central bank's response to the crisis was effective and consistent with the long-accepted principles of Bagehot (1873) (e.g., Madigan, 2009). Critics, however, argue that the Fed's actions did little to alleviate financial strains (Taylor and Williams, 2009), contributed to instability (Meltzer, 2009), and may have helped sow the seeds of future crises by protecting creditors of large financial firms (Buiter, 2009; Poole, 2009). ${ }^{1}$ Clearly, there remain many unsettled questions about how central banks should carry out their responsibilities as lenders of last resort.

This paper examines the origins and early performance of the Federal Reserve as lender of last resort. We believe that a look back at the successes and failures of central banks in the past can inform current discussions about how central banks should act as lenders of last resort. Here we consider why the Fed's performance as lender of last resort, especially during the Great Depression, failed to live up to the promises of those who designed the System. The Fed was established to overcome the problems of the National Banking era. Those problems, which included seasonal money market stringency and recurrent banking panics, had brought calls for reform by the 1870s. Following the Panic of 1907, Congress enacted the Aldrich-Vreeland Act of 1908 which established the National Monetary Commission, as well as a temporary mechanism for increasing the supply of currency during banking panics. The studies of the National Monetary Commission identified defects of the U.S. banking system and drew lessons from the performance of banking systems in other countries. One study in particular argued that the Panic of 1907 and earlier crises revealed the superiority of the European "discount system” and the vital role played by central banks in maintaining financial stability. The study's author, Paul Warburg (Warburg, 1910a), convinced Nelson Aldrich, the powerful chairman of the Senate Banking Committee, of the efficacy of the European system, and Aldrich became the principal champion of a central banking system for the United States.

\footnotetext{
${ }^{1}$ Information about the Federal Reserve's response to the financial crisis of 2007-08 is available on the Federal Reserve Board of Governors website (http://www.federalreserve.gov/monetarypolicy/bst_crisisresponse.htm). For a summary, see Wheelock (2010).
} 
Aldrich convened the now famous Jekyll Island meeting of November 1910 where he met with a small group of leading bankers, including Warburg, to determine how to organize and operate the proposed central bank. The bill Aldrich submitted to Congress in 1912 was the product of that meeting. It included many features that reflected Warburg's desire to emulate the European systems. Aldrich proposed a National Reserve Association that would oversee the operations of a system of local and regional reserve associations and set a discount rate at which the local branches would rediscount notes and bills of exchange for member banks (Wicker, 2005). Congress, which then was controlled by Democrats, rejected the Aldrich bill. However, the Federal Reserve Act of 1913 resembled the Aldrich bill in many respects, including the provisions concerning the rediscounting of commercial paper and bills of exchange for member banks, which were fundamental to how the central bank would serve as lender of last resort to the banking system.

Neither the Aldrich bill nor the Federal Reserve Act dealt explicitly with financial crises nor prescribed how the Fed should respond to banking panics. The authors believed that their proposed reforms would prevent banking panics from occurring in the first place. Indeed, the United States had no banking panics during the first 15 years of the Fed's existence, despite the occurrence of several shocks, including a world war, a short, but severe post-war recession, and the failure of several thousand mostly small, rural banks during the 1920s. Banking panics returned with a vengeance during the 1930s, however, and the Fed's failure to prevent or counteract panics was, many believe, a principal cause of the Great Depression (e.g., Friedman and Schwartz, 1963; Bernanke, 1983). Numerous explanations for the Fed's failures during the Depression have been suggested, including defects in the System's structure and leadership, the Fed's devotion to the gold standard, and policymakers' misreading of monetary conditions. Although each of these likely contributed to the Fed's highly deflationary monetary policy, we believe that there is more to the story, especially as to why the Fed failed to prevent or offset serious banking panics.

We trace the Fed's failure to act as an effective lender of last resort during the Great Depression to defects of the Federal Reserve Act and, more broadly, of the U.S. banking system. In particular, the Act failed to recreate the money market conditions and other institutions that enabled the Bank of England and other European central banks to function effectively as lenders 
of last resort. In addition, the Act created a system that depended critically on the competence of the individuals running the system—a point which Friedman and Schwartz (1963) emphasizerather than a set of rules or principles to guide lender of last resort policy. Finally, and perhaps at least as importantly, the Federal Reserve Act failed to replace the crisis-prone U.S. unit banking system with a more stable, concentrated branch banking system, such as those of the United Kingdom and Canada.

The following section briefly describes the defects of the National Banking System identified by the National Monetary Commission and others, and the European discount system that advocates saw as the appropriate reform. Next we discuss how the Federal Reserve System was intended to overcome the flaws of the National Banking System by creating a discount mechanism to supply bank reserves and currency as needed to support economic activity and avoid panics. We then examine how well this mechanism performed, and consider why the Fed failed to serve effectively as lender of last resort during the Great Depression. The Fed's failures led to numerous reforms in the mid-1930s, including expansion of the Fed's lending authority and changes in the System's structure, as well as changes that made the U.S. banking system less prone to banking panics. Finally, we consider lessons about the design of lender of last resort policies that might be drawn from the Fed's early history.

\section{Banking Reform}

\section{Defects of the National Banking System}

The recurrent instability of the National Banking era was the principal motivation for the reform movement that led to the Federal Reserve Act. A related impetus was the desire to enhance the international role of the dollar and to have a central bank to manage the gold standard (Broz, 1997). The United States experienced numerous bank failures, banking panics, and persistent seasonal stringency in the money market throughout the nineteenth century, which reflected two fundamental problems: 1) unit banking; and 2) the absence of an effective lender of last resort.

Unit banking resulted from legal restrictions imposed by the federal government on interstate branch banking and by most states on branching within state borders. Unit banking made it difficult for banks to pool risks and exposed them to local and regional shocks. Further, 
it hampered their ability to grow in size and scope to satisfy the credit and payments requirements of their major business customers, especially toward the end of the nineteenth century when large industrial firms with national operations were becoming more prevalent (Calomiris, 1993; 1995). Unit banking was largely a U.S. phenomenon. Over time, the banking systems of Canada and most European countries became increasingly dominated by small numbers of large banks with nation-wide branches (Bordo, Redish and Rockoff 1996; Grossman 2010).

Branching restrictions and the absence of a central bank reflected deep seated populist fears about the concentration of financial power. Alexander Hamilton, the first U.S. Secretary of the Treasury, established a prototypical central bank in 1791. The federally-chartered First Bank of the United States was inspired by the experience of the Bank of England. The Bank acted as the government's fiscal agent, provided a uniform national currency and promoted economic development. Its large capitalization and nationwide scope (it had branches in every state) allowed it to evolve quickly into a bankers’ bank for the nation's nascent state-chartered banks. In 1811, the Bank's twenty year charter was not renewed amid allegations of corruption and populist and states-rights opposition to its power (Timberlake, 1993). A second federal bank was chartered in 1816, with a similar charter as the First Bank and a similar fate. Under the direction of its president, Nicholas Biddle, the Second Bank was even more successful than the First Bank in providing a uniform national currency by effectively policing the note issues of the state banks and performing many central banking functions (Knodell, 2003). The Bank encouraged and backstopped the development of a liquid market in bills of exchange (two-name paper) and on occasion provided liquidity to correspondent banks in times of stringency, actions similar to those undertaken by the Bank of England at this time (Broz, 1997). It also conducted exchange market policy to manage the gold standard (Bordo, Humpage and Schwartz, 2007).

Andrew Jackson vetoed the bill to re-charter the Second Bank in 1836. The demise of the Second Bank left the chartering and regulation of banks entirely to the states, the majority of which enacted free banking laws in the 1830s and 1840s. These laws significantly reduced entry barriers into banking and permitted banks to issue notes based on the collateral of eligible bonds. The Free Banking era of 1836-63 was characterized by a multiplicity of bank notes circulating at varying rates of discount reflecting the soundness of the banks and the distance from the issuer 
(Gorton, 1996), frequent bank failures, in some states fraud (“wildcat banking”), and several serious panics (1837, 1839, 1857) (Rockoff, 1974; Temin, 1969). ${ }^{2}$ The National Banking Acts of 1863 and 1865 were intended to overcome perceived flaws of the free banking era, as well as to create a demand for U.S. government debt. Under the National Banking system, a uniform currency emerged in the form of national bank notes backed by U.S. government bonds. National banks had higher reserve and capital requirements than the banks chartered by most states, and were supervised by the U.S. Comptroller of the Currency. State bank notes were taxed out of existence, but state banks continued to thrive under more lax state regulation as deposit-taking institutions (White, 1983).

The National Banking system prevailed for fifty years. Although it created a uniform national currency, the system itself had several serious defects that reformers viewed as responsible for a series of banking panics in 1873, 1884, 1890, 1893 and 1907 that were as severe as the major antebellum panics. Reformers identified three problems in the U.S. banking system: 1) an "inelastic" currency stock; 2) seasonal stringency in the money market; and 3) an “inverted pyramid” of banking system reserves.

\section{Inelastic Currency}

The framers of the National Banking system sought to avoid the periodic suspensions of convertibility of bank notes into specie or other forms of high-powered money that plagued the free banking era by requiring national banks to pledge U.S. government bonds as security for their currency liabilities. The remedy, however, resulted in an inflexible currency stock that did not vary rapidly or sufficiently to meet normal seasonal variation in economic activity let alone extraordinary demands.

Under the National Banking system, the stock of national bank notes could expand only via an increase in the volume or value of U.S. government bonds held by national banks, which were unlikely during the short period of a crisis. Through local clearinghouses, banks developed ways to conserve reserves and expand high-powered money by issuing emergency currency in the form of clearinghouse certificates (Timberlake, 1984; Gorton, 1985). Beginning with the

\footnotetext{
${ }^{2}$ A revisionist literature has downplayed the defects of free banking. Losses to note holders were minimal, wildcatting occurred in only a few states and information about the quality of individual state bank note issues was widely available (Rockoff, 1974; Rolnick and Weber, 1983; Gorton, 1996).
} 
panic of 1857, the New York Clearing House issued loan certificates to its member banks based on the discounted value of the collateral they posted in proportion to each bank's share of the total assets of the clearinghouse. These certificates served as substitutes for reserves which allowed member banks to pay out cash that otherwise would have been tied up in interbank settlements. In the panic of 1873, the New York Clearing House pooled the reserves of the member banks. Later, in the panics of 1893 and 1907, clearinghouse currency was issued in exchange for loan certificates. This arrangement provided depositors with insurance against the failure of individual banks and discouraged runs. The issuance of clearinghouse certificates was sufficient to allay crises in 1884 and 1890 but not other crises of the era. The U.S. Treasury also intervened on occasion during panics to add reserves to the banking systems by depositing tax and customs receipts in New York banks and by other methods. These interventions were often too little and too late (Schwartz, 1986). Banking panics in 1873, 1893 and 1907 ended only after the suspension of convertibility of deposits into currency.

\section{Seasonal Stringency}

Banking reformers noted that financial crises tended to occur at times of the year when the demands for currency and credit peaked. Seasonal fluctuations in credit demand produced seasonal swings in interest rates and in the ratio of reserves to deposits in the banking system (Miron, 1986). Capital inflows relieved the seasonal pressures to some extent (Goodhart, 1969). However, if an unusual gold outflow or a shock to the domestic financial market, such as major bank failure or stock market crash, occurred at a seasonal peak in currency and credit demand, a banking panic was more likely to occur (Sprague, 1910; Kemmerer, 1910).

\section{Inverted Pyramid of Reserves}

Reform advocates pointed to the distribution of reserves across the banking system as a third problem with the National Banking system. Under the National Banking system, national banks were required to maintain minimum levels of reserves against their deposit liabilities, which were intended to prevent excessive deposit expansion and to protect banks in the event of runs (Bordo, Rappoport and Schwartz, 1992, pp 211-213). National banks located in small cities and rural areas (i.e., “country” national banks) were subject to a 15 percent reserve requirement, of which three-fifths could be held as balances with correspondent banks in reserve cities (cities 
with populations greater than 50,000) or in central reserve cities (New York, Chicago and St. Louis). The remaining two-fifths of required reserves were to be held in lawful money (U.S. notes, specie, gold and clearing house certificates). National banks in reserve cities were required to hold 25 percent of their deposits in reserves, half of which had to be held in lawful money, the other half as balances on deposit in central reserve city national banks. Central reserve city national banks were required to hold 25 percent of their deposits in lawful money. Country and reserve-city banks tended to hold the maximum allowable amount of reserves in the form of deposit balances in central reserve cities.

The reserve structure of the national banking system was described as an inverted pyramid because much of the nation's bank reserves were held in the form of correspondent balances in a handful of banks in the central reserve cities, especially New York City (Myers, 1931; James, 1978). Most of the reserves held as correspondent balances in New York City were invested in the call loan market. Call loans were demand loans secured by equities traded on the New York stock exchange and by U.S. government and other bonds. Most call loans were made to brokers who would then consign the securities serving as collateral to the banks. Commercial banks considered call loans their most liquid investment.

The New York City national banks dominated the call loan market—close to 75 per cent of bankers balances in New York were held in call loans (Myers, 1935, p. 290). In addition, country and reserve-city national banks, state commercial banks, savings banks and trust companies all invested directly in the call loan market (using their central reserve city correspondents as intermediaries) whenever the call loan rate rose significantly above the 2 percent rate normally paid on correspondent balances. Thus an inverse relationship existed between the call loan rate and correspondent balances in New York City, and a direct one between the call loan rate and country bank excess reserves invested directly in the call loan market (Myers, 1931, p. 290; James, 1978, p. 304).

The inverted pyramid of reserves and the intimate connection between the correspondent balance system and the call loan market were widely regarded as key elements in the financial crises of the National Banking era (Sprague, 1910). All of the major banking panics were marked by withdrawals of correspondent balances by the country and reserve-city banks from the New York banks. The decline in correspondent balances in turn put pressure on the call loan market, 
causing call loan rates to rise sharply and stock prices to fall. The decline in the reserves of New York City banks could be so severe as to precipitate a panic, which could be stopped only by a suspension of convertibility of deposits into currency or by the issuance of clearinghouse loan certificates.

A related critique of the National Banking system was that banks viewed the reserves they held to meet the minimum requirements as unavailable in a crisis. Banks rarely were willing to let their actual reserve holdings fall below the minimum because of the possible legal sanctions that might be imposed; hence reserves were not an effective line of defense in the event of a bank run (Cagan, 1963; West, 1977, pp. 30-31).

\section{The Reform Movement}

The first wave of reform proposals followed the 1873 panic and focused on the pyramiding of banking system reserves. Several proposals called for prohibiting the payment of interest on interbank deposits as a way of discouraging banks from holding reserves in the form of correspondent balances, but none resulted in legislation (West, 1977, Chapter 2).

A second wave of reform proposals followed the panic of 1893. They focused on making the currency stock more elastic by replacing the nation's “bond-backed” currency, i.e., national banknotes backed by government bonds, with an “asset-backed” currency tied to banks’ holdings of commercial paper. The American Bankers Association's Baltimore Plan of 1894 was one of the first to call for a currency backed by commercial paper. A similar plan was recommended by J. Laurence Laughlin at the Indianapolis Monetary Convention in 1897. Laughlin, a professor of economics at the University of Chicago, was a strong proponent of the real bills doctrine. He argued that basing the currency stock on self-liquidating short-term commercial paper (real bills) used to finance commerce, industry and agriculture would always prevent over- or under-issue. Laughlin's views became more influential as momentum for reform built up in the next decade (Mehrling, 2002; Broz, 1997). ${ }^{3}$

The Aldrich-Vreeland Act of 1908 was an important step in the reform movement. In addition to creating the National Monetary Commission, the Aldrich-Vreeland Act

\footnotetext{
${ }^{3}$ Other proposals to improve banking stability included reserve pooling, issuing emergency currency as done by the clearinghouses and adopting Canadian-style nationwide bank branching (West, 1977, Chapter 2).
} 
institutionalized the emergency currency provisions developed by major clearinghouses to alleviate banking panics. The Act permitted groups of ten or more national banks to form currency associations to issue emergency currency in the event of a crisis equal to as much as 75 percent of the value of commercial paper deposited with the association. The Act also permitted individual banks to issue notes if authorized by the Secretary of the Treasury. Currency issued under the Aldrich-Vreeland Act was subject to tax to ensure its speedy retirement after an emergency had passed. Aggregate circulation under the Act was limited to $\$ 500$ million (Friedman and Schwartz, 1963, Chapter 3). The Aldrich-Vreeland Act was a temporary measure and it was only used once, to stem a crisis in 1914 at the outbreak of World War I (Wicker, 2005; Silber, 2007).

Nelson Aldrich, Chairman of the Senate Committee on Banking and Currency, remained at the center of the banking reform movement. As noted previously, he was persuaded of the efficacy of the European-style discount and central banking system by Paul Warburg, a partner in the firm of Kuhn Loeb. Warburg had been a successful banker in Germany before immigrating to the United States in 1902. Based on his experience and knowledge of the operations of the German Reichsbank, the Bank of England and the Banque de France, Warburg made the case for a European-style central bank for the United States. He argued that in the advanced countries of Europe the presence of a discount market and a central bank that provided liquidity to back up the market and serve as lender of last resort in times of stringency prevented the type of financial instability experienced in the United States (Warburg, 1910a). Warburg believed that a market for bills of exchange (two-name bills), as exemplified by the market for bankers acceptances, would be more liquid than the existing U.S. commercial paper market (which was based on single-name promissory notes). Acceptances were short-term instruments in which the IOU issued by, e.g., a merchant to one of his suppliers, would be guaranteed (accepted) by a bank. The bank's reputation would allow the bill to be traded in an open market and hence provide liquidity.

Two types of acceptances were used in Europe: trade acceptances used to finance domestic trade (inland bills in England), and bankers acceptances used to finance international trade. The latter type of bill was not legal in the United States during the National Banking era 
and the former had declined in use after the Civil War. ${ }^{4}$ Warburg argued that the U.S. money market would be more liquid if banks were permitted to issue bankers acceptances. In addition, he noted that the creation of a U.S. acceptance market would break the monopoly that sterling bills (bankers acceptances drawn on British merchant banks) had over U.S. international commerce and help the dollar become an international currency (Broz, 1997).

Warburg believed that recreating as closely as possible the money market environment of England, France and Germany was a crucial step in bringing stability to the U.S. banking system. The European financial system in the late nineteenth century, especially the most highly developed one in England, was both sophisticated and complex. The Bank of England took many years to evolve into an effective lender of last resort and money market maker that Aldrich, Warburg and the other New York bankers so admired. The Bank was chartered in 1694 as a joint stock bank of issue and served as the government's fiscal agent. The Bank's charter required that its liabilities be convertible into gold at the official parity. Over time, the Bank's strong capitalization and position as the government's bank enabled it to become a bankers' bank. However, it did not always act as a true lender of last resort in times of panic because of its responsibility to its shareholders (Goodhart, 1987). Only after the Overend Gurney crisis of 1866 did the Bank accept Bagehot's Responsibility Doctrine and agree to subsume its private interest to the public good in times of crisis (Bordo, 1990).

The English financial system had become very sophisticated by the middle of the nineteenth century. It consisted of merchant banks which financed international trade, bill brokers which dealt in bills of exchange, discount houses which evolved from bill brokers and purchased and rediscounted bills, and commercial banks. The market for bills of exchange (acceptances) was both deep and liquid (Bignon, Flandreau and Ugolini, 2009).

Discount houses, such as Overend Gurney, had gained considerable prominence in the English market by the mid-nineteenth century. The discount houses acted as intermediaries

\footnotetext{
${ }^{4}$ The two-name bill was a common financial instrument in the United States before the Civil War and Biddle's Second Bank of the United States helped make it the kind of liquid market that Warburg favored. The two-name bill declined markedly after the Civil War, however, because of the currency instability during the Greenback period which made it difficult to make longer term contacts. It was replaced by single-name promissory notes and the commercial paper market developed considerably by the end of the nineteenth century (James, 1995). The commercial paper market, however, was not as liquid as the two-name bill markets in Europe.
} 
between commercial banks and the Bank of England. When in need of liquid funds, the commercial banks would turn to the discount houses to rediscount their paper, and the discount houses in turn would go to the Bank of England for accommodation. The discount houses would pass their bills to the Bank, which would judge the quality of the paper offered as collateral and return cash if the collateral was deemed acceptable. According to Capie (2002, p. 311), the Bank lent anonymously to the market:

The mechanism can be envisaged as the central bank having a discount window made of frosted glass and raised just a few inches. Representatives of institutions could appear at the window and push through the paper they wanted discounted. The central banker would return the appropriate amount of cash, reflecting the going rate of interest. The central banker does not know, nor does he care, who is on the other side of the window. He simply discounts good quality paper or lends on the basis of good collateral. In this way, institutions holding good quality assets will have no difficulty in obtaining the funds they need. Institutions with poor quality are likely to suffer. In times of panic the interest rate would rise.

Thus, the Bank of England did not as a rule lend to individual banks, but to the market. The Bank’s discount rate, "Bank Rate," served as an anchor to the financial system. In times of crisis the Bank followed Bagehot's strictures: 1) to lend freely in the face of an internal drain (a domestic liquidity crisis) and to discount all sound collateral; 2) to charge a high rate in the face of an external drain (an outflow of gold reserves); and 3) to lend freely at a high rate when faced with both an internal and external drain.

Bagehot is commonly believed to have said "lend freely at a penalty rate" to discourage moral hazard. But, according to Goodhart (1987), Bagehot used the term "high" and not “penalty.” Moreover, according to Bignon, Flandreau and Ugolini (2009), there is considerable confusion in the subsequent literature over the term "penalty" and that by the 1850s the Bank rarely discounted paper that would be subject to moral hazard. In the years following Bagehot's Lombard Street (1873), the Bank never faced another banking panic (Schwartz, 1986; Capie, 2002).

Warburg was most familiar with the German system. Germany also had a well developed discount market and a highly concentrated banking system. As Warburg (1910a) describes, the 
German banks discounted directly with the Reichsbank (Wicker, 2005). ${ }^{5}$ Germany faced only one minor banking crisis in 1901 (Bordo and Eichengreen, 2002).

The institutional frameworks of the European banking systems that Warburg admired were very different from that of the United States in the National Banking era. The European banking systems were relatively concentrated, dominated by large banks with nation-wide branches, and had active markets in bankers acceptances, which could be rediscounted with a central bank. By contrast, the United States had thousands of small unit banks, no acceptance market, and no central bank. Would the new Federal Reserve regime adapt U.S. institutions to match the performance of the pre-1914 European central banks? Unit banking remained in the United States after the Fed was established, as did the "dual” banking system in which some banks are chartered and supervised by national authorities and others by state authorities. With its system of semi-autonomous regional Reserve Banks, the Federal Reserve System was made to fit the structure of the U.S. banking system. Warburg pushed for the development of a bankers acceptance market in the United States. The Federal Reserve Act permitted national banks to issue bankers acceptances and authorized the Federal Reserve Banks to purchase acceptances in the open market. The U.S. acceptance market never became large, however, and fell off sharply during the Depression. Thus, a key element of the original Warburg plan was never realized.

\section{The Warburg-Aldrich Plan}

Warburg (1910b) first proposed the creation of a central bank with 20 regional branches controlled by bankers but regulated, to some extent, by government officials. His proposed United Reserve Bank would rediscount bills of exchange for its member banks, thereby providing liquidity to the market and establishing a lender of last resort that, following Bagehot's strictures, would lend freely in a banking panic:

The relationship between the central bank and the discount market is a most important one. While in normal times only a small proportion of the business is done by the central bank, the existence of this bank is all important to the whole financial structure, because even if a bank makes it a rule not to rediscount with the central bank and in its general business keeps independent of this institution, the fact remains that in case of need it can nevertheless rediscount with the central bank every legitimate bill, both bankers or mercantile acceptance, so that every legitimate bill represents a quick asset, on the realization of which every bank or banker can rely. Consequently no investor, bank,

\footnotetext{
${ }^{5}$ The French system was similar to the German system (Broz, 1997).
} 
banker, private capitalist or financial institution will ever hesitate to buy good bills. Furthermore, there will not be in critical times any rush to sell good bills, as everybody in these countries knows that there is no better and safer investment, because for no other investment is there an equally reliable market. (Warburg, 1910a, p. 14)

Echoing Bagehot (1873), Warburg (1910a, p. 37) explained how the central bank should respond to crises:

Thus certain periodic and normal demands for cash, as well as a domestic drain caused by distrust, must be met by paying out freely. A foreign drain, on the other hand, must generally be met by an energetic increase of the rate, while a drain both domestic and foreign must be treated by various combinations of both methods. (Warburg, 1910a, p. 37)

Under Warburg's plan, the discount rate would be the key instrument of policy, but it would be supplemented by open market operations to help make the discount rate effective, i.e., to ensure that changes in the discount rate could always determine the behavior of market rates (Sayers, 1957). As in Europe, adherence to the official gold parity would anchor the price level. The United Reserve Bank would issue currency backed by gold and bills of exchange, and manage the gold standard, i.e., intervene in the exchange market and manipulate the gold points, in accordance with the "rules of the game" as the European central banks did (Bordo, Humpage and Schwartz, 2007).

Warburg argued that a discount market would replace the call loan market as the principal source for liquidity for U.S. banks. This in turn would eliminate, in his opinion, a key source of financial instability—-the link between the stock market and the banking system.

The Aldrich bill drafted at Jekyll Island was similar in many ways to the Warburg plan. The Aldrich bill called for the establishment of a National Reserve Association, headquartered in Washington D.C. The Association's branches would be located throughout the United States and serve member commercial banks. The Association would issue asset-backed currency and rediscount eligible paper consisting of short-term commercial and agricultural loans for its members at a discount rate set by the National Association's board of directors. The discount rate would be uniform throughout the nation. The Association also would be permitted to conduct open market operations and exchange market intervention. 


\section{The Federal Reserve Act}

Congress rejected the Aldrich bill. Popular distrust of Wall Street power and of bankers in general ("the money trust") killed it. Moreover, when the Democrats took control of Congress in the election of 1912, the Aldrich bill was considered anathema. Yet, under the direction of Carter Glass, the new Chairman of the Senate Banking and Currency Committee, and with the aid of his advisor H. Parker Willis (a student of J. Laurence Laughlin and strong advocate of the real bills doctrine), a bill was put forward in early 1913 for what became the Federal Reserve Act. The Act almost completely replicated the key monetary and international policy provisions of the Warburg plan and the Aldrich bill (Wicker, 2005). The initial Glass bill was later modified to include important revisions requested by President Woodrow Wilson to increase government oversight of the System, and the bill became known as the Glass-Owen bill (Robert Owen was Chairman of the House Committee on Banking and Currency).

The Federal Reserve System differed markedly from Aldrich's proposed National Reserve Association in terms of structure and governance. Rather than a central organization with many branches, the Federal Reserve System consisted of twelve semi-autonomous regional Reserve Banks and the Federal Reserve Board, which had a general oversight role. Whereas the Federal Reserve Board was made up of of five members appointed by the President and chaired by the Secretary of the Treasury, the Reserve Banks were owned by their member banks and managed by officers appointed by local boards of directors. ${ }^{6}$ A key difference between the Federal Reserve Act and the Aldrich plan was that the individual Federal Reserve Banks set their own discount rates (subject to review by the Federal Reserve Board) and each Bank was required to maintain a minimum reserve in the form of gold and eligible paper against its note and deposit liabilities.

\section{LLR Provisions of the Federal Reserve Act}

The preamble to the Federal Reserve Act states that it is an "Act to provide for the establishment of Federal Reserve banks, to furnish an elastic currency, to afford means of rediscounting commercial paper, to establish a more effective supervision of banking in the

\footnotetext{
${ }^{6}$ Federal Reserve Bank boards of directors consist of nine directors, three of whom, including the chairman and vice chairman, are appointed by the Board of Governors, and six (three bankers and three others) elected by the Reserve Bank's member banks. The member banks are required to purchase stock in their local Reserve Bank.
} 
United States, and for other purposes.” The Act does not contain explicit instructions for how the Fed should respond in the event of a banking panic, in other words, how it should serve as lender of last resort. Apparently, the authors of the Act believed that they had created a fool-proof mechanism that would prevent panics from occurring in the first place. ${ }^{7}$

The Federal Reserve Act also did not address sources or forms of financial instability outside the banking system. For example, although trust companies had been at the epicenter of the Panic of 1907, the Act did not permit Federal Reserve membership for most trust companies, as well as mutual savings banks, building and loan companies or other non-bank financial institutions. Membership was required only of national banks. State-chartered banks were permitted to become Fed members if they agreed to the same minimum capital, reserve and other requirements imposed on national banks. Only member banks were given access to Fed services, including the discount window, although the Act left open the possibility that discount window loans could be extended to nonmember banks in special circumstances with the approval of the Federal Reserve Board.

Relatively few state-chartered banks joined the Federal Reserve System. By June 1915, only 17 state banks had become Fed members. Membership grew slowly to a peak of 1,620 statechartered banks (compared with 19,345 nonmember banks) in June 1923. Member banks tended to be larger than nonmembers, however, and by June 1915 member banks held nearly half the total deposits of all U.S. commercial banks ( $\$ 8.9$ billion versus $\$ 9.1$ billion held by nonmember commercial banks). Still, even by June 1923, member banks held less than two-thirds of total U.S. commercial bank deposits ( $\$ 27.1$ billion versus $\$ 10.6$ billion in nonmember banks). ${ }^{8}$

The Fed's member banks were required to maintain reserve balances with the Federal Reserve Banks, which the founders expected would reduce the concentration of correspondent balances held in the central money markets and invested in stock market call loans, and thereby lessen the transmission of instability from the stock market to the banking system. Reformers argued that the flow of surplus funds to the central money markets, principally New York City, and invested in stock market loans had contributed to market instability and reduced the supply

\footnotetext{
${ }^{7}$ Senator Claude A. Swanson stated optimistically that the Federal Reserve Act made "impossible another panic in this country." (quoted in Hackley, 1973, p. 10).

${ }^{8}$ These data are from Board of Governors of the Federal Reserve System (1943, pp. 16-17).
} 
of credit available for commercial and agricultural borrowers, especially outside the principal financial centers.

To address the problem of an inelastic currency (defined broadly to include both currency and bank reserves), the Federal Reserve Act permitted member banks to rediscount eligible paper with Federal Reserve Banks in exchange for currency (Federal Reserve notes) or reserve deposits. Federal Reserve notes were asset-backed in the sense that the Reserve Banks were required to hold reserves in the form of eligible commercial paper or gold equal to their outstanding note issues (plus an additional 40 percent gold reserve). The stocks of Federal Reserve notes and member bank reserve deposits were elastic in that their volumes would vary with the amount of eligible paper that member banks rediscounted with the Reserve Banks, which in turn varied with fluctuations in the demands for currency and credit.

The Federal Reserve Act imposed two checks on the amount of notes and bank reserve deposits the Fed could issue. First, each Reserve Bank was required to maintain gold reserves equal to at least 40 percent of its outstanding notes and 35 percent of its deposit liabilities. Federal Reserve Banks were further required to hold eligible paper equal to 100 percent of their outstanding note issues. ${ }^{9}$ The Federal Reserve Act did not specify the criteria that Reserve Banks were to use in setting their discount rates, but clearly it was expected that a Reserve Bank would increase its discount rate as necessary to maintain adequate gold reserves.

The Federal Reserve Act also limited the types and maturities of loans and securities that member banks could rediscount with the Reserve Banks, which served as a second brake on Federal Reserve credit. Glass and Willis were strong proponents of the real bills doctrine who believed that Federal Reserve credit should be extended only by the rediscounting of short-term, self-liquidating commercial and agricultural loans. The Act permitted rediscounting of "notes, drafts, and bills of exchange arising out of actual commercial transactions," but forbid rediscounting of loans or securities "covering merely investments or issued or drawn for the purpose of carrying or trading in stocks, bonds or other investment securities, except bonds and notes of the Government of the United States.” Further, the Federal Reserve Act specified that

\footnotetext{
${ }^{9}$ An amendment to the Federal Reserve on June 21, 1917, reduced the amount of eligible paper that the Reserve Banks were required to hold from 100 percent to 60 percent of their outstanding note issues (the 40 percent gold reserve requirement against their note issues was retained).
} 
only those loans with a term to maturity of 90 days or less (180 days for agricultural loans) were eligible for rediscount. In setting a maximum term, Congress cited the experience of other countries. For example, Senator John F. Shafroth stated:

When we look around in the history of the world we find that ... in England the paper [that is eligible for rediscounting] must run only 28 days, ... in France it runs but 26 days, ... in Germany it does not exceed 90 days, and that there is no bank in the world which discounts paper in excess of 90 days... [Does] it not become us, in the interest of caution, to say that until it is demonstrated the other way we had better adhere to 90-day paper? (Quoted in Hackley, 1973, p. 14)

The provisions of the Federal Reserve Act defining eligible paper were similar to those in the Aldrich bill. However, the Aldrich bill would have permitted rediscounting of any direct obligation of the borrowing bank if approved by the Secretary of the Treasury and the bank's local association which, as Wicker (2005, p. 86) notes, might have been particularly helpful during a banking panic. The Glass-Steagall Act of 1932 amended the Federal Reserve Act to permit the Fed to extend loans on the basis of any satisfactory collateral in emergency situations (Hackley, 1973, p. 100).

The Federal Reserve Act granted access to the Fed's discount window only to member banks. Further, the Act specified that "no member bank shall act as the medium or agent of a nonmember bank in applying for or receiving discounts from a Federal Reserve Bank ... except by permission of the Federal Reserve Board.” The provision granting the Board authority to permit exceptions was not in either the House or Senate versions of the Act, but was added in conference committee (Hackley, 1973, p. 119). During World War I, the Board authorized the Reserve Banks to discount for nonmembers, with the endorsement of a member bank, notes secured by U.S. Government securities if the proceeds were to be used for holding government securities (Hackley, 1973, pp. 118-19). Then in 1921, the Board authorized the Reserve Banks to discount for member banks any eligible paper acquired from nonmember banks, but that authority was rescinded in 1923 (Hackley, 1973, p. 119). Thereafter, Federal Reserve credit was extended to nonmember banks only in exceptional circumstances with Board approval. One such occurrence helped to end a local banking panic in Florida in 1929 (Carlson et al., 2010). However, in general, nonmember banks were shut out from Federal Reserve loans, which was especially problematic during the Great Depression when banking panics arose among nonmember banks. 
Fundamentally, the provisions of the Federal Reserve Act pertaining to the discount window were those advocated by Warburg and contained in the Aldrich bill. ${ }^{10}$ Warburg's views were also reflected in sections of the Act that permitted member banks to offer bankers acceptances based on international trade, and which authorized the Federal Reserve Banks to rediscount or purchase acceptances in the open market. Similar to the discount rates they set for the rediscount of eligible paper, the Reserve Banks set rates of discount ("bill buying rates”) on acceptances they offered to purchase in the open market. The Fed's acceptance buying facility was closer in form to the Bank of England's discount facility than the Fed's discount window. Typically, the Reserve Banks would purchase all of the eligible acceptances offered to them at their set bill buying rates. If the U.S. acceptance market had developed to the extent it had in England (or in Germany) in the nineteenth century, it is conceivable that the Fed would have been a more effective lender of last resort during the Great Depression. However, as discussed in the next section, the U.S. acceptance market remained small and fell off sharply during the Depression. Although the Federal Reserve purchased a significant share of outstanding acceptances, those purchases generally were not a significant source of Federal Reserve credit during the Depression.

The Fed's Performance as Lender of Last Resort to 1933

In addition to creating the Federal Reserve System, the Federal Reserve Act also extended for one year a provision of the Aldrich-Vreeland Act of 1908 that permitted commercial banks to form associations to issue emergency currency backed by commercial paper or certain long-term bonds in the event of a banking panic. Some $\$ 375$ million of emergency currency was issued under the terms of the act when bank runs occurred at the start of World War I in August 1914. The response is widely credited with stemming the panic and ensuring continued loan growth (e.g., Sprague, 1915; Friedman and Schwartz, 1963; Wicker, 2005, pp. 44-49).

The Federal Reserve Banks began to operate in November 1914, but were minor players in the money market until the United States entered World War I in 1917 (West, 1977, pp. 181-

\footnotetext{
${ }^{10}$ Wicker (2005) argues that Warburg was not a proponent of the real bills doctrine and that the Federal Reserve Act was "real bills neutral" because it did not require that the paper eligible for rediscounting with the Fed be "self liquidating." Meltzer (2003, p. 70), however, contends that Warburg held the view that "the Federal Reserve could prevent wide swings in interest rates without risking inflation if it purchased real bills.”
} 
86). The Fed then helped to finance the war effort by offering preferential discount rates on loans ("advances") to member banks secured by government bonds. ${ }^{11}$ The Reserve Banks also purchased over $\$ 1$ billion of government securities in the open market.

In deference to the Treasury Department, the Fed maintained preferential discount rates on loans secured by government securities for some months after the war ended. The Fed regained its independence and began to raise its discount rate (and end preferential rates) in December 1919. The continued expansion of Federal Reserve credit after the war significantly reduced the Reserve Banks’ gold reserve ratios, from a post-war peak of 50.6 percent in June 1919 to a low of 40.6 percent in March $1920 .^{12}$ The falling reserve ratio was a principal motivation for raising the discount rate, though the Fed also sought to control inflation and to limit stock market speculation (Wicker, 1966, pp. 37-45).

The Reserve Banks maintained their discount rates at high levels even after inflation had ceased to be a threat and economic activity had begun to decline. Both wholesale prices and industrial production fell sharply in 1920, but the Fed did not reduce its discount rate until May 1921 when officials were confident that the Reserve Banks could maintain their reserve ratios (Chandler, 1958, p. 186).

The Fed was heavily criticized, both for post-war inflation and the subsequent deflation and decline in economic activity. Perhaps partly in response to this criticism, there appears to have been a marked change in Fed policy after 1921 that is evident in the System's use of openmarket operations in government securities. By 1923, the Reserve Banks had formed a committee to coordinate their open-market operations and a Special System Investment Account was established at the Federal Reserve Bank of New York in December 1923 to handle the committee’s operations. Friedman and Schwartz (1963, Chapter 6) refer to the period from 1921 to 1929 as the "High Tide" of the Federal Reserve System, during which the Fed, under the leadership of New York Fed governor Benjamin Strong, pursued a well-conceived monetary policy that promoted economic stability and low inflation. Although other studies have been

\footnotetext{
${ }^{11}$ An amendment to the Federal Reserve Act in 1916 permitted member banks to borrow directly from Federal Reserve Banks using eligible paper as collateral, which gave banks an alternative to rediscounting eligible paper to obtain Federal Reserve notes or reserve deposits.

12 This is an aggregate of the ratios of total reserves to deposits and Federal Reserve notes for all twelve Reserve Banks (Board of Governors of the Federal Reserve System, 1943, p. 346).
} 
more critical of Strong and his policies (e.g., Meltzer, 2003), economic activity and the price level were remarkably stable during this period. Moreover, despite the failures of several hundred mostly small, rural banks, there were no episodes of banking distress or panic in the major financial centers. It seemed that the Federal Reserve Act had indeed solved the problems that had produced recurrent banking panics during the $19^{\text {th }}$ and early $20^{\text {th }}$ centuries.

The elimination of seasonal tightness in credit markets and interest rates was a principal goal of the Fed's founders, who had noted that banking panics tended to occur at times of the year when the demands for currency and credit were at seasonal peaks. The Fed seems to have accomplished this objective as seasonal variation in money market interest rates dropped sharply after the Fed's founding (Miron, 1986; Friedman and Schwartz, 1963, pp. 292-93). Federal Reserve credit exhibited a distinct seasonal pattern throughout the 1920s, reflecting increases in both discount window borrowing and Fed purchases of bankers acceptances at times of the year when currency and credit demands reached seasonal peaks, and decreases in discount window borrowing and in the Fed's acceptance holdings when seasonal demands ebbed (see Figure 1). ${ }^{13}$

Seasonal accommodation was largely automatic, as the Fed's founders had intended. At relatively fixed discount rates on loans to member banks and on purchases of acceptances in the open market, the Reserve Banks made more discount window loans and purchased more bankers acceptances at times of the year when demands for credit and currency were high. Unfortunately, the Great Depression demonstrated that accommodating seasonal variation in money and credit demand was not sufficient to eliminate the problem of banking panics. ${ }^{14}$

\section{The Great Depression}

The Fed's policy failures during the Great Depression are legendary. The Fedspecifically, the Federal Reserve Bank of New York—reacted swiftly to the October 1929 stock market crash by lowering its discount rate and lending heavily to banks, and by purchasing government securities in the open market. However, the Fed largely ignored the banking panics

\footnotetext{
13 Figure 1 plots total Federal Reserve credit and credit extended through the discount window and by Federal Reserve purchases of bankers acceptances. The data shown are monthly averages of daily figures (Board of Governors of the Federal Reserve System, 1943, pp. 369-71).

${ }^{14}$ Miron (1986) contends that the Fed was less accommodative of seasonal demands during the Depression, which could explain the increased incidence of financial crises. However, Wheelock (1992) finds that any changes in the seasonal patterns of interest rates and Federal Reserve credit after 1929 were not statistically significant.
} 
and failures of 1930-33, and did little to arrest large declines in the price level and output. The Fed clearly failed to serve effectively as lender of last resort.

Fed Policy from the Stock Market Crash to Bank Holiday

Figure 2 shows the level and composition of Federal Reserve credit during 1929-34, providing one measure of the Fed's response to the major financial crises of the Great Depression. In the figure, we plot the sum of Federal Reserve discount window loans and holdings of bankers acceptances (labeled “Federal Reserve loans”), as well as Federal Reserve holdings of U.S. government securities and other sources of Federal Reserve credit (mainly float).

Following the stock market crash, the Federal Reserve Bank of New York used openmarket purchases and liberal discount window lending to inject reserves into the banking system, which enabled New York City banks to absorb a large amount of loans made by securities brokers and dealers. The New York Fed's actions were "timely and effective" in containing the crisis and preventing widespread panic in money markets and among bank depositors (Friedman and Schwartz, 1963, p. 339). The Federal Reserve Board reluctantly approved the New York Fed's actions ex post, but many members expressed displeasure that the New York Fed had acted independently.

The New York Fed pressed for additional easing in early 1930. However, the Federal Reserve Board rejected several requests for discount rate cuts and additional open-market purchases. As Figure 2 shows, total Federal Reserve credit fell by about one-third during the first half of 1930, mainly because of declines in discount window loans and Fed purchases of bankers' acceptances. As Figure 3 shows, the monetary base and broader measures of the money stock mirrored Federal Reserve credit outstanding-increasing sharply after the stock market crash, but then falling with the decline in Fed credit during 1930. Friedman and Schwartz (1963) contend that the decline in the money stock was the main cause of the subsequent decline in economic activity. ${ }^{15}$

\footnotetext{
${ }^{15}$ Friedman and Schwartz's (1963) monetary explanation of the Great Depression is widely, but not universally accepted among economists. See Parker (2007) for a survey of alternative views on the causes of the Great Depression.
} 
The stock market crash was the first in a series of financial shocks during the Great Depression. Friedman and Schwartz (1963) identify major banking panics in the fourth quarter of 1930, early 1931, fourth quarter of 1931, and in February-March 1933. As Figure 2 shows, total Federal Reserve credit surged briefly following the stock market crash, and during the banking panics of October-December 1930, September-December 1931 (which followed the United Kingdom's decision to leave the gold standard), and January-March 1933. On each occasion, the increase in Federal Reserve credit (and its impact on the monetary base) was quickly reversed. Moreover, as Figure 3 shows, when Federal Reserve credit finally began to grow in 1932, it only temporarily halted the decline in the broader money stock.

Why did the Fed permit Federal Reserve credit to contract after each financial shock of 1929-33? Meltzer (2003) argues that Fed officials misinterpreted the signals coming from money market interest rates and discount window borrowing. Following the policy guidelines that Federal Reserve Bank of New York Governor Benjamin Strong and his colleagues had developed during the 1920s, policymakers inferred that low levels of interest rates and borrowing meant that monetary conditions were exceptionally easy, and that there was no benefit, and possibly some risk, from putting more liquidity into the banking system. ${ }^{16}$ Strong explained the use of the level of discount window borrowing as a guide to policy as follows:

Should we go into a business recession while the member banks were continuing to borrow directly 500 or 600 million dollars ... we should consider taking steps to relieve some of the pressure which this borrowing induces by purchasing government securities and thus enabling member banks to reduce their indebtedness.... As a guide to the timing and extent of any purchases which might appear desirable, one of our best guides would be the amount of borrowing by member banks in the principal centers.... Our experience has shown that when New York City banks are borrowing in the neighborhood of 100 million dollars or more, there is then some real pressure for reducing loans, and money rates tend to be markedly higher than the discount rate. On the other hand, when borrowings of these banks are negligible ... the money situation tends to be less elastic and if gold imports take place, there is liable to be some credit inflation, with money rates dropping below our discount rate. When [New York City] member banks are owing us about 50 million dollars or less the situation appears to be comfortable, with no marked pressure for liquidation. ${ }^{17}$

\footnotetext{
${ }^{16}$ According to Meltzer (2003), the Fed's monetary policy in the 1930s and even in the 1950s and later was based on the guidelines developed by Strong and his colleagues W. Randolph Burgess and Winfield Riefler to guide openmarket policy in the 1920s (the so-called Riefler-Burgess Doctrine).

${ }^{17}$ Presentation to the Federal Reserve Governors’ Conference, March 1926 [quoted by Chandler (1958, pp. 239-40].
} 
Discount window borrowing declined sharply, from \$500 million for all Federal Reserve member banks in January 1930 (\$39 million for New York City banks) to \$231 million in April 1930 (\$17 million for New York City banks), and \$226 million in July 1930 (\$0 for New York City banks). Fed officials interpreted the decline as indicating that monetary conditions were extremely easy, and that additional stimulus was not required. For example, the governor of the Federal Reserve Bank of San Francisco argued in June 1930 that, "with credit cheap and redundant, we do not believe that business recovery will be accelerated by making credit cheaper and more redundant." ${ }^{18}$ Indeed, some officials described monetary conditions as too easy and argued for a tighter policy. For example, in January 1930, the governor of the Federal Reserve Bank of Minneapolis wrote that "I cannot see the desirability of further ease of credit. It seems to me money is getting almost 'sloppy." "19 Several Fed officials believed that Federal Reserve credit should be withdrawn whenever economic activity slows. For example, the governor of the Federal Reserve Bank of Philadelphia stated: "We have been putting out credit in a period of depression, when it was not wanted and could not be used, and will have to withdraw credit when it is wanted and can be used.”20

Federal Reserve credit increased temporarily in late 1930, as shown in Figure 2. Federal Reserve credit normally rose in the autumn when loan demand and interest rates tended to rise. However, in December 1930, the Federal Reserve Bank of New York also purchased \$175 million of U.S. government securities and bankers acceptances to ease financial market strains that appeared following the failure of the Bank of United States. Numerous banks failed throughout the United States between October and December 1930. Most were small banks that were not members of the Federal Reserve System, and thus unable to borrow at the Fed's discount window. ${ }^{21}$ Friedman and Schwartz (1963) note that Fed officials felt no particular responsibility for nonmember banks. However, they argue that the Fed made a critical error in not saving the Bank of United States, which was a mid-size New York City bank and a member of the Federal Reserve System. Although the Federal Reserve Bank of New York participated in

\footnotetext{
${ }^{18}$ Quoted by Chandler (1971, p. 118).

${ }^{19}$ Quoted by Chandler (1971, p. 143).

${ }^{20}$ Minutes of the Open Market Policy Conference, September 25, 1930 [quoted by Chandler (1971, p. 137]. See Chandler (1971) and Meltzer (2003) for information about the policy views expressed by different Federal Reserve officials during the Depression.

${ }^{21}$ Before the Monetary Control Act of 1980, only Federal Reserve member banks had access to the Fed's discount window.
} 
discussions about a possible merger to save the Bank of United States, those talks broke down when neither the New York Fed nor the New York clearinghouse banks would guarantee \$20 million of Bank of United States assets (Meltzer, 2003, pp. 323-24). Instead, the Fed and clearinghouse elected to let the Bank of United States fail and focus on containing the resulting fallout.

Federal Reserve credit outstanding declined sharply in early January, 1931, as money market strains eased. However, in 1931, the economic contraction deepened, deflation took hold, and interest rates and discount window borrowing declined still further. Another wave of bank failures occurred in the first half of 1931, but again most of the banks that failed were nonmember banks located outside of New York City and other financial centers. For the first time, banks began to hold excess reserves, i.e., reserves in excess of legal requirements. Fed officials took this as further evidence of exceptionally easy monetary conditions, and considered engaging in open-market sales to “soak up” excess liquidity (Meltzer, 2003, p. 328).

The next major financial shock occurred in late September 1931. After running through most of its gold and foreign exchange reserves, the United Kingdom abandoned the gold standard on September 21, 1931, and allowed the pound to float freely. Speculation that the United States would soon also leave the gold standard caused large withdrawals of gold and currency from U.S. banks. The Federal Reserve responded by increasing its discount and acceptance buying rates in an attempt to halt and then reverse the gold outflow, and to demonstrate the System's resolve to maintain the gold standard. Federal Reserve officials interpreted their response to the gold outflow as being consistent with Bagehot's rule to lend freely at a high interest rate (Meltzer, 2003, p. 348). The Fed did not make significant openmarket purchases to offset the withdrawal of gold and currency from banks, however, which exacerbated the decline in the monetary aggregates (see Figure 3). Moreover, when gold began to flow back into the banking system, Federal Reserve credit outstanding fell by more than the gold inflow, which resulted in a net decline in total bank reserves. Fed officials apparently were hesitant to make open-market purchases because they saw a "disinclination on the part of 
member banks to use Federal Reserve credit for the purpose of extending credit to their customers."22

Besides doubting that open-market purchases would serve any useful purpose, at least some Fed officials were concerned that large open-market purchases would threaten the System's gold reserves. Although researchers subsequently have concluded that the Fed did have sufficient gold reserves to make significant open-market purchases (e.g., Friedman and Schwartz, 1963; Bordo, Choudhri and Schwartz 2002), Fed officials may have been concerned that large purchases would have touched off a resumption of gold outflows (Wicker, 1966). In any event, the excuse became moot when Congress enacted legislation in February 1932 that enabled the Fed to use U.S. government securities as collateral for Federal Reserve notes. ${ }^{23}$ Under pressure from Congress, the Fed then purchased approximately \$1 billion of government securities between February and August, 1932.

Discount window loans totaled \$848 million when the Fed began to purchase government securities in February 1932 and, hence, monetary conditions were tight according to the Fed's traditional policy guide. Discount window borrowing declined and banks began to build up substantial excess reserves as the Fed continued its purchases. Several Fed officials interpreted the increase in excess reserves as indicating that the Fed's purchases had little benefit. The Fed ended its purchases when the level of discount window borrowing had fallen to what it had been before Britain left the gold standard. Nonetheless, the purchases caused Federal Reserve credit to rise substantially (see Figure 2), which for a few months arrested the decline in the money stock (see Figure 3).

The final and most severe banking crisis of the Depression began in February 1933. Banking panics, marked by heavy withdrawals of currency and gold reserves, swept across the United States. As it had done in response to gold outflows in 1931, the Fed reacted by increasing its discount and acceptance buying rates. Federal Reserve credit increased sharply in March, 1933, as discount window loans rose from \$253 million on February 8 to \$1.4 billion on March 8, and the Fed purchased some $\$ 400$ million of bankers acceptances. The Fed also purchased

\footnotetext{
${ }^{22}$ Federal Reserve Bank of New York Governor George Harrison [quoted by Meltzer (2003, p. 350)].

${ }^{23}$ The Federal Reserve Act required each Reserve Bank to maintain gold reserves equal to 40 percent of its note issue and reserves in the form of gold or other eligible securities (which did not include U.S. Treasury securities) equal to the remaining 60 percent. See Friedman and Schwartz (1963, pp. 399-406).
} 
\$100 million of government securities, but this was far too little to offset the decline in bank reserves caused by currency and gold withdrawals. In response to a request from the Secretary of the Treasury for larger purchases of government securities, Federal Reserve governor Eugene Meyer replied that a rise in bond yields was a "necessary readjustment in a market which has been too high," and that "Purchases of Government securities at the present time would be inconsistent from a monetary standpoint." ${ }^{24}$ Instead of supplying additional liquidity to the banking system, the Federal Reserve Board voted to suspend the Fed's gold reserve requirement and to recommend that President Hoover declare a national bank holiday. This action and many others were subsequently taken by President Roosevelt on his first day in office on March 5, 1933.

Why Did the Fed Fail to Act as Lender of Last Resort During the Depression?

Many studies have considered why the Federal Reserve failed to act effectively as lender of last resort during the Great Depression. Friedman and Schwartz (1963) emphasize the Fed's decentralized structure and lack of strong leadership. Without a forceful leader, they argue, the System was paralyzed by in-fighting, petty jealousies, and sharp differences of opinion. Other studies downplay the significance of the Fed's structure, contending that the policies pursued by the Fed during the Depression were fundamentally consistent with those of the 1920s (e.g., Wicker, 1966; Wheelock, 1991; Meltzer, 2003). Those studies contend that Fed officials misinterpreted the behavior of nominal interest rates and the level of borrowing from the Fed's discount window. Officials interpreted low nominal interest rates and little borrowing at the discount window as evidence that monetary conditions were exceptionally easy and that there was little more the Fed could or should do to promote economic recovery.

Still other studies focus on the role of the gold standard (Temin, 1989; Eichengreen, 1992). The Federal Reserve Act affirmed the fundamental role that the gold standard played in the U.S. monetary system. Federal Reserve Banks were required to maintain gold reserves to back their note and deposit liabilities. Although the Act permitted the Federal Reserve Board to suspend the System's gold reserve requirement, Fed officials were deeply committed to

\footnotetext{
${ }^{24}$ Quoted by Meltzer (2003, p. 385).
} 
maintaining the gold standard and were extremely reluctant to take any action that would threaten or even that might be perceived as threatening the gold standard.

We believe that the Fed's decentralized structure, misreading of monetary conditions, and commitment to the gold standard all contributed to the Fed's highly deflationary monetary policy of 1929-33 and limited response to banking panics. However, we also believe that there is more to the story, especially as to why the Fed failed to prevent or offset serious banking panics during the Depression. In particular, we argue that the Federal Reserve Act failed to recreate the features of the British banking system that made the Bank of England an effective lender of last resort during the late $19^{\text {th }}$ and early $20^{\text {th }}$ centuries. Or, similarly the features of the German banking system that made the Reichsbank an effective lender of last resort that Warburg admired. Further, we argue that the restrictions on discount window lending imposed by the Federal Reserve Act were both too limiting and left too much to the discretion of policymakers in administering the discount window to make it an effective mechanism for responding to banking panics.

\section{The Discount Window-A Flawed LLR Mechanism}

The authors of the Federal Reserve Act intended the discount window to be the primary means by which the Fed would "furnish an elastic currency." The authors sought to provide a mechanism that would ensure ample supplies of currency and bank reserves to support commercial and agricultural activity, but not be a source of funds for speculation or long-term investment. Accordingly, the types of loans and securities that were eligible for rediscounting with Federal Reserve Banks were restricted to short-term commercial and agricultural paper (and U.S. government securities). During the Depression, many banks apparently lacked paper that was acceptable for rediscounting with Federal Reserve Banks (or that could be used as collateral for advances from the Fed) under the Federal Reserve Act. Although the total amount of eligible paper (government securities and private commercial paper and acceptances) far exceeded the amount of discount loans made by the Fed, holdings of eligible paper varied widely across banks of different sizes and across Federal Reserve districts (Chandler, 1971, pp. 227-33). According to Chandler (1971, p. 232), "the narrow definition of eligible assets, symbolizing a persistence of 
commercial loan ideas, contributed to bank closings and to liquidation of credit by banks that succeeded in remaining open.”25

A second problem with the discount mechanism as designed and implemented under the Federal Reserve Act was that member banks were apparently quite reluctant to borrow from the Fed in the event of a crisis. In part this reluctance reflected the Fed's administration of the discount window. Throughout the 1920s, Fed officials had tried to discourage banks from continuous borrowing and sought to instill the idea that banks are hesitant to borrow from the Fed and do so reluctantly when confronted with a short-term liquidity need (see Meltzer, 2003, pp. 161-65, for discussion). A number of Fed officials, especially members of the Federal Reserve Board, were concerned that banks were borrowing from the Fed to finance loans for the purchase of stocks. In February 1929, the Federal Reserve Board directed the Reserve Banks to crack down on banks that were borrowing from the Fed and simultaneously making speculative loans: “A member bank is not within its reasonable claims for rediscount facilities at its Federal Reserve Bank when it borrows either for the purpose of making speculative loans or for the purpose of maintaining speculative loans” (quoted in Chandler, 1971, pp. 56-57). The message clearly was that the Reserve Banks should administer the discount window more tightly and that member banks should think twice before coming to the Fed for a loan.

The reluctance to borrow at the discount window took on another dimension during the Depression, when bank depositors became concerned about the condition of the banks in which they held funds. According to Friedman and Schwartz (1963, pp. 318-19), “The aversion to borrowing by banks, which the Reserve System had tried to strengthen during the twenties, was still greater at a time when depositors were fearful for the safety of every bank and were scrutinizing balance sheets with great care to see which banks were likely to be the next to go.” Wheelock (1990) estimates a model of the demand for discount window loans as a (nonlinear) function of the spread between the discount rate and a market interest rate, the change in

\footnotetext{
${ }^{25}$ The Federal Reserve Act was amended in February 1932 to add Section 10(b), which permitted Federal Reserve Banks to lend to any member bank with capital not exceeding \$5 million on the basis of any satisfactory assets, whether or not technically eligible for rediscount, in exceptional and exigent circumstances. Section 10(b) loans required the approval of at least five members of the Federal Reserve Board and bore an interest rate not less than 1 percent above the regular discount rate. Section 10(b) was set to expire in March 1933, but was extended for one year by the Emergency Banking Act of 1933. Subsequent amendments made permanent changes to the Federal Reserve Act that permitted discount window loans on any satisfactory assets of the borrowing bank. The appendix lists major statutory changes affecting Federal Reserve discount window lending.
} 
nonborrowed reserves, and a measure of economic activity, and finds evidence that the demand for discount window loans shifted downward during the Depression. This suggests greater reluctance (or inability) of banks to borrow at the discount window during the Depression than during the 1920s, and that the discount mechanism was not well suited for ameliorating a banking panic. Further, it suggests that the level of discount window borrowing was an especially poor indicator of monetary conditions during the Depression.

\section{Bankers Acceptance Purchases as an Alternative to the Discount Window}

A second mechanism for supplying currency or bank reserves in the event of a crisisFederal Reserve purchases of bankers acceptances_-also failed to prevent or counteract banking panics during the Depression. The Fed did make large purchases of bankers acceptances during banking panics in the fall of 1931 and in March 1933, but the purchases were not large enough to offset the effects of currency and gold withdrawals from the banking system.

The 1931 panic was triggered by the United Kingdom’s departure from the gold standard on September 21. Speculation that the United States would soon follow Britain off the gold standard precipitated large withdrawals from U.S. banks. The Fed responded to the crisis by raising its discount rates on discount window loans and acceptance purchases in an effort to discourage gold outflows and to shore up confidence in the Fed's resolve to stay on the gold standard. Despite the higher cost of borrowing from the Fed, both discount window borrowing and sales of acceptances to the Fed rose sharply. Discount window loans increased from \$263 million on September 16 to $\$ 698$ million on October 21, and peaked at \$1,024 million on December 30. The Fed's holdings of acceptances rose from \$218 million on September 16 to a peak of $\$ 769$ million on October 21. Despite the increases in discount loans and Fed purchases of acceptances, the total reserves of Fed member banks fell by $\$ 142$ million between September 16 and October 21, and continued to fall until the end of February 1932. The Fed allowed its acceptance portfolio to dwindle. After peaking at $\$ 769$ million on October 21, the Fed's acceptance holdings declined to \$327 million on December 30, and continued to fall steadily to under \$100 million by mid-March 1932.

The banking crisis of 1933 resulted in a similar short-lived increase in both discount window loans and Fed purchases of bankers acceptances. Discount loans increased sharply from 
\$327 million on February 27 to $\$ 1,414$ million on March 15, while the Fed's holdings of acceptances rose from $\$ 180$ million to $\$ 417$ million. These increases, however, were insufficient to replace all of the reserves the banking system lost to outflows of currency and gold.

Although the Fed's purchases of bankers acceptances provided some support to the banking system during the panics, the acceptance market was small and highly concentrated in New York City, which limited the usefulness of Fed purchases in a crisis. The size of the acceptance market fell sharply from about $\$ 1.6$ billion at the end of 1929 to around $\$ 700$ million by mid-1932 (Balabanis, 1935). For comparison, as of September 16, 1931, the reserves of Federal Reserve member banks totaled \$2.4 billion. Moreover, the market was concentrated in New York City, and most banks outside of New York City held few, if any, acceptances they could sell to the Fed. ${ }^{26}$ The Fed purchased approximately 80 percent of the outstanding acceptances in October 1931 and 50 percent in March 1933 (Balabanis, 1935). Conceivably, the Fed could have made it more attractive for banks to sell acceptances to the Reserve Banks by lowering their bill buying rates, but it seems doubtful that they could have purchased enough acceptances to prevent declines in bank reserves, especially in 1931 and early 1932.

\section{The Fed's Decentralized Structure}

The authors of the Federal Reserve Act emphasized that they were not creating a U.S. central bank, but rather a federal system of Reserve Banks that would respond to and support the banking and currency needs of their individual districts. Accordingly, each Reserve Bank had the discretion to set its own discount rate and to administer its discount window, and each was required to satisfy a reserve requirement. The purpose of this structure was to reduce the concentration of the banking system's reserves in the central money markets, especially New York City, and to limit the power of New York and Washington over the nation's banks and economy. The Fed's decentralized structure, however, proved unwieldy, especially in responding to financial crises. Friedman and Schwartz (1963) contend that the Fed's failures during the Great Depression stemmed from a lack of effective leadership, which enabled parochial interests and petty jealousies to hamstring policy. The individual Reserve Banks acted competitively,

\footnotetext{
${ }^{26}$ Friedman and Schwartz (1963, p. 404n) report that only New York City banks held bankers acceptances. Paul Warburg viewed the failure of large, active acceptances markets to develop outside of New York City as the system’s principal failure (cited by Meltzer, 2003, p. 119n).
} 
rather than cooperatively, at critical points during the Depression. For example, in March 1933, the Federal Reserve Bank of Chicago refused a request from the New York Fed to exchange gold for U.S. government securities when gold outflows threatened to push the New York Bank's reserve ratio below its legal minimum (Meltzer, 2003, p. 387). Although the Federal Reserve Board eventually required the Chicago Fed and other Reserve Banks to lend to New York, the episode illustrates how the System's structure hampered its response to crises. The Banking Acts of 1933 and 1935 addressed this by substantially increasing the authority of the Federal Reserve Board over both discount and open-market policy.

Although the authors of the Federal Reserve Act sought to impose a rule that would guarantee adequate supplies of currency and bank reserves to support economic activity and prevent banking panics, in fact, the Act left considerable discretion to the individual Reserve Banks and the Federal Reserve Board for implementing policy. Some of the Reserve Banks were more liberal in determining and valuing acceptable discount window collateral than others (Chandler 1971, p. 233). In addition, some of the Reserve Banks moved more aggressively than others to supply currency to banks threatened by a panic. According to Richardson and Troost (2009), the Federal Reserve Bank of Atlanta responded to local panics by moving large quantities of cash to affected regions, extending emergency loans to member banks, and helping member banks extend loans to nonmember banks. Comparing the performance of the Atlanta and St. Louis Federal Reserve Banks during a 1930 banking panic that straddled both districts, Richardson and Troost (2009) conclude that the Atlanta Fed's more aggressive response to the panic kept bank failure rates lower, and commercial lending and economic activity higher, in the Atlanta district than in the St. Louis district.

Further evidence that officials of the Federal Reserve Bank of Atlanta were aggressive in responding to banking distress is reported in Carlson, Mitchener and Richardson (2010), which investigates a banking panic that arose in Florida in 1929. The study reports that the Atlanta Fed shipped large amounts of currency to the afflicted region to shore up the confidence of bank depositors, and that the Reserve Bank secured permission from the Federal Reserve Board to lend to nonmember institutions. The study concludes that the Bank's swift action stopped the panic and held down the number of bank failures. 
A third example of discretion on the part of a Reserve Bank was the Federal Reserve Bank of New York's aggressive response to the 1929 stock market crash. Following the crash, the New York Fed extended discount window loans liberally to member banks so that they could take on stock exchange loans held by brokers. The Bank also purchased more than \$100 million of government securities in the open market.

The actions by the Federal Reserve Banks of Atlanta and New York suggest that the Federal Reserve had the tools and the power to respond effectively to financial crises. However, an effective response required leaders who were willing to improvise and test the limits of the Federal Reserve Act. The Act did not provide an automatic, fool-proof mechanism for dealing with crises, as the founders had hoped. Instead, effective lender of last resort action depended a great deal on the discretion of individual policymakers.

\section{$\underline{\text { Conclusion }}$}

The lender of last resort provisions of the Federal Reserve Act mimicked features of the Aldrich bill of 1912, which in turn originated with the Warburg plan of 1910. In particular, Warburg envisioned that the central bank would rediscount bankers acceptances to backstop a highly liquid and deep money market like those of England and other advanced European countries, and to provide lender of last resort facilities in the event of a financial crisis.

The Fed navigated its first 15 years without any banking panics. It succeeded in smoothing out seasonal fluctuations in short-term interest rates which had contributed to instability in the National Banking era. The Federal Reserve failed to prevent a series of banking panics in the early 1930s, however, which worsened the Great Depression. An extensive literature has posited several explanations for the Fed's failure. These include: 1) Flaws in the System's structure which impeded coordination between the Federal Reserve Board and the Reserve Banks, especially after the death of New York Fed Governor Benjamin Strong in 1928 (Chandler, 1958; Friedman and Schwartz, 1963); 2) Devotion to the gold standard which kept the Fed from following expansionary policies to offset banking panics (Temin, 1989; Eichengreen, 1992); and 3) Adherence to a flawed policy framework that relied on nominal interest rates and the level of discount window borrowing as policy guides (Meltzer, 2003; Wheelock, 1991). 
We argue that a fourth important factor was the failure of the Federal Reserve Act to provide a discount mechanism and money market environment of the sort that had enabled the Bank of England and other European central banks to function effectively as lenders of last resort. This was manifest in three flaws: 1) The reluctance of member banks to turn to the discount window in times of stress (the "stigma” problem); 2) The Fed's limited membership and the fact that except in extreme circumstances, only member banks had access to the discount window; and 3) The restrictive eligibility requirements on collateral posted for borrowing at the Fed's discount window. Furthermore, the Federal Reserve Act did nothing to reform the inherently unstable unit banking system. A better alternative might have been to allow nationwide branch banking and consolidation of the banking industry as in Canada and the United Kingdom, which over time proved to be a more stable market structure with less need for a lender of last resort (Bordo, Rockoff, and Redish, 2010).

The Federal Reserve Act sought to create a U.S. bankers acceptance market and offered support to that market by authorizing the Reserve Banks to purchase bankers acceptances in the open market. The Fed's acceptance purchase facility was similar to the Bank of England's discount window in that the Fed purchased all of the eligible acceptances offered to it, much as the Bank of England rediscounted all good quality bills offered by dealers under its "frosted glass” discount window. The acceptance facility had at least two characteristics that seem good lender of last resort practice: 1) lending was to the market, rather than to individual institutions or classes of institutions, against a standard financial instrument; and 2) the facility entailed little scope for hesitation or discretion, except in setting the discount ("bill buying”) rate. Bankers acceptances never became the core instrument of the U.S. money market, however, and the acceptance market fell off sharply during the Depression. Thus the United States never developed the money market conditions that had enabled European central banks to be effective lenders of last resort before World War I. ${ }^{27}$

In response to the disaster of the early 1930s, the Banking Acts of 1933 and 1935 made significant changes in the structure and authority of the Federal Reserve System. The Acts

\footnotetext{
27 The U.K. bill market also declined in the 1920s and 1930s. According to Holden (1955, p. 302), declining international trade and changing trade patterns reduced the demand for bills to finance international trade during the Great Depression, while the greater stability of the Brutish banking system, which resulted from a merger wave that increased concentration, "made it no longer necessary for bankers to guard against the consequences of a panic or run upon the banks by discounting bills.”
} 
concentrated policymaking authority within the Board of Governors, expanded the Fed's ability to lend on the basis of any sound collateral, and authorized the Fed to lend to nonbank financial institutions in a crisis (the infamous Section 13(3)). In addition, the banking system was subject to major reforms, including the introduction of federal deposit insurance, the forced separation of commercial and investment banking (Glass-Steagall); the regulation of deposit interest rates (Regulation Q), and strict limits on market entry. These reforms were intended to enhance the Fed's ability to respond to crises while making the banking system less prone to instability.

What are the lessons of the Fed's early experience as lender of last resort? The Fed's early history provides much information about what does not work. In particular, it shows that a lender of last resort system that works well in one environment may not work in another environment. A lender of last resort structure should match the financial environment. Paul Warburg sought to emulate the European central bank mechanism and discount market. For political economy reasons (especially the deep ingrained fear of concentration of financial power), U.S. banking institutions were not fully adapted to the European system (e.g., the U.S. retained a dual state and federal banking system, maintained unit banking, and the single name commercial paper market remained dominant after the Fed was founded). The Federal Reserve Act overcame some of the flaws of the National Banking System (e.g., the inelastic currency) that promoted instability, but not all of them. Perhaps the Fed's lender of last resort mechanism would have performed better with a Canadian-European style branch banking system coupled with a deep acceptance market.

Amendments to the Federal Reserve Act in the 1930s addressed many of the technical flaws that had caused the Fed to be an ineffective lender of last resort in the Depression. In addition, other reforms promoted stability of the banking system (e.g., deposit insurance, the Glass-Steagall separation of commercial and investment banking). But these created a banking system that was slow to innovate, and lost business to less-regulated financial institutions and markets (the "shadow" banks).

The reforms of the 1930s focused on protecting bank depositors and preventing runs by depositors, and hence they proved only partly helpful during the crisis of 2007-08. As with the original Federal Reserve Act, the 1930's reforms did not contemplate how to protect the banking system from instability coming from outside the banking system (e.g., runs on investment 
banks). The Section 13(3) lending programs created by the Fed in 2007-08 were, for the most part, helpful in alleviating the crisis, but required considerable discretion and judgment on the part of Fed officials - there was no playbook to follow, so policymakers had to invent on the fly. Moreover, the Fed seemed to have had no way to save the financial system without resorting to bailouts (e.g., AIG), and these actions may cause other problems (e.g., bailouts lead to moral hazard and compromise the Fed's independence)

A key lesson of both the Fed's early experience and the crisis of 2007-08 is that the tools of a lender of last resort must match the financial environment. A lender of last resort mechanism must adapt to be effective. It remains to be seen whether the reforms of 2010 have got it right. We now will have a Financial Stability Council charged with keeping track of key risks to the financial system and regulating systemically-important firms and markets. We now will have an expedited mechanism for winding down troubled large non-bank financial institutions. We also have prevented the Fed from making Section 13(3) loans to individual firms (no more bailouts?). Will it all work to protect the financial system from the next crisis? Only time will tell. 


\section{References}

Bagehot, Walter (1873). Lombard Street: A Description of the Money Market. London: H.S. King \& Co.

Balabanis, Homer P. (1935). The American Discount Market. Chicago: University of Chicago Press.

Bernanke, Ben S. (1983). "Nonmonetary Effects of the Financial Crisis in Propagation of the Great Depression.” American Economic Review 73 (no. 3), June, pp. 257-76.

Bignon, Vincent; Flandreau, Marc; and Stefano Ugolini (2009). “ Bagehot for Beginners: The Making of Lending of Last Resort Opeartions in the mid $19^{\text {th }}$ Century.” Norges Bank Working Paper.

Board of Governors of the Federal Reserve System (1943). Banking and Monetary Statistics, 1914-1941. Washington, D.C.

Bordo, Michael D. (1990). “The Lender of Last Resort: Alternative Views and Historical Experience.” Federal Reserve Bank of Richmond Economic Review January/February.

Bordo, Michael D. and Barry Eichengreen (2002). "Crises Now and Then: What Lessons from the Last Era of Financial Globalization.” In Paul Mizen (ed.), Monetary History, Exchange Rates and Financial Markets: Essays in Honor of Charles Goodhart, Vol. 2 London: Edward Elgar, pp. 52-91.

Bordo, Michael D. Choudhri Ehsan and Anna J. Schwartz ( 2002) "Was Expansionary Monetary Policy Feasible During the Great Contraction”. Explorations in Economic History. January.

Bordo, Michael D.; Humpage, Owen; and Anna J. Schwartz (2007). "The Historical Origins of U.S. Exchange Market Intervention Policy.” International Journal of Finance and Economics 12 (no. 2), April, pp. 109-132.

Bordo, Michael D.; Rappoport, Peter; and Anna J.Schwartz (1992). "Money Versus Credit Rationing: Evidence for the National banking Era, 1880-1914.” In Claudia Goldin and Hugh Rockoff (eds.), Strategic Factors in Nineteenth Century American Economic History, A Volume to Honor Robert W. Fogel. Chicago: University of Chicago Press, pp. 189-224.

Bordo, Michael D.; Redish, Angela; and Hugh Rockoff (2010). "Why Didn’t Canada Have a Banking Crisis in 2008 (or in 1930, or 1907, or 1893)? Presented at the Economic History Association Annual Meeting, September 24, 2010. 
Bordo, Michael D.; Redish, Angela; and Hugh Rockoff (1996). "A Comparison of the Stability and Efficiency of the Canadian and American Banking Systems, 1870-1925," Financial History Review 3 (no. 1), pp. 49-68.

Broz, J. Lawrence (1997). The International Origins of the Federal Reserve System. Ithaca: Cornell University Press.

Buiter, Willem (2009). “The Fed’s Moral Hazard Maximising Strategy.” FT.com/maverecon, March 6. http://blogs.ft.com/maverecon/2009/03/the-feds-moral-hazard-maximisingstrategy/

Cagan, Philip (1963). “The First Fifty Years of the Federal Reserve.” In Deane Carson (ed.), Banking and Monetary Studies. Homewood, Illinois: Richard D. Irwin.

Calomiris, Charles W. (1995). "The Costs of Rejecting Universal Banking: American Finance in the German Mirror.” In Naomi Lamoreaux and Daniel Raff (eds.), The Coordination of Activity Within and Between Firms. Chicago: University of Chicago Press.

Calomiris, Charles W. (1993). "Regulation, Industrial Structure, and Instability in U.S. Banking: An Historical Perspective.” In Michael Klausner and Lawrence J. White (eds.), Structural Change in Banking. Business One-Irwin.

Capie, Forrest (2002). “The Emergence of the Bank of England as a Mature Central Bank.” In Donald Winch and Patrick O'Brien (eds.), The Political Economy of British Historical Experience 1688-1914. London: Oxford University Press, pp. 295-315.

Carlson, Mark; Mitchener, Kris James; and Gary Richardson (2010). "The Florida Banking Panic of 1929: Real Shocks, Runs and Intervention.” Working paper, Department of Economics, University of California at Irvine.

Chandler, Lester V. (1971). American Monetary Policy 1928-1941. New York: Harper and Row.

Chandler, Lester V. (1958). Benjamin Strong, Central Banker. Washington, D.C.: Brookings Institution.

Eichengreen, Barry (1992). Golden Fetters: The Gold Standard and the Great Depression, 19191939. New York: Oxford University Press.

Friedman, Milton and Anna J. Schwartz (1963). A Monetary History of the United States 18671960. Princeton: Princeton University Press.

Goodfriend, Marvin (2009). “Central Banking in the Credit Turmoil: An Assessment of Federal Reserve Practice.” Prepared for the Bank of Japan 2009 International Conference, “Financial System and Monetary Policy Implementation,” May 27-28.

Goodhart, Charles (1987). The Evolution of Central Banks. Cambridge, Mass: MIT Press. 
Goodhart, Charles (1969). The New York Money Market and the Finance of Trade: 1900-1913. Cambridge Mass: Harvard University Press.

Gorton, Gary (1996). “Reputation Formation in Early Bank Note Markets.” Journal of Political Economy 104 (no.2), April, pp. 346-397.

Gorton, Gary (1985). “Clearing Houses and the Origin of Central banking in the United States.” Journal of Economic History 45, June, pp. 277-83.

Grossman, Richard S. (2010). Unsettled Account: The Evolution of Banking in the Industrialized World Since 1800. Princeton: Princeton University Press.

Hackley, Howard H. (1973). Lending Functions of the Federal Reserve Banks: A History. Washington, D.C.: Board of Governors of the Federal Reserve System.

Holden, J. Milnes (1955). The History of Negotiable Instruments in English Law. London: University of London. The Athlone Press.

James, John (1978). Money and Capital Markets in Postbellum America. Princeton: Princeton University Press.

James, John (1995). “The Rise and Fall of the Commercial Paper Market, 1900-1929.” In Michael D. Bordo and Richard Sylla (eds.), Anglo-American Financial Systems: Institutions and Markets in the Twentieth Century. New York: Irwin.

Kemmerer, Edwin W. (1910). Seasonal Variations in the Relative Demand for Money and Capital in the United States. National Monetary Commission, Senate Document No. 588, 61 Cong. 2 Sess. Washington: Government Printing Office.

Knodell, Jane (2003). "Profit and Duty in the Second Bank of the United States Exchange Operations.” Financial History Review 10, pp 5-30.

Madigan, Brian F. (2009). "Bagehot's Dictum in Practice: Formulating and Implementing Policies to Combat Financial Crisis.” Remarks at the Federal Reserve Bank of Kansas City’s Annual Economic Symposium, Jackson Hole, Wyoming, August 21, 2009.

Meltzer, Allan H. (2009). "Regulatory Reform and the Federal Reserve.” Testimony before the Subcommittee on Monetary Policy, House Committee on Financial Services, July 9, 2009.

Meltzer, Allan H. (2003). A History of the Federal Reserve, Volume 1: 1913-1951. Chicago: University of Chicago Press.

Mehrling, Perry (2002). "Economists and the Fed beginnings." Journal of Economic Perspectives 16, Fall, pp. 207-218.

Miron, Jeffrey A. (1986). "Financial Panics, the Seasonality of the Nominal Interest Rate, and the Founding of the Fed.” American Economic Review 76 (no. 1), March, pp. 125-40. 
Myers, Margaret (1931). The New York Money Market: Origins and Development. New York: Columbia University Press.

Parker, Randall E. (2007). The Economics of the Great Depression: A Twenty-First Century Look Back at the Economics of the Interwar Era. Cheltenham, UK: Edward Elgar.

Poole, William (2009). “The Bernanke Question.” Cato Institute Commentary, July 28. www.cato.org/pub-display.php?pub id=10388.

Richardson, G. and William Troost (2009). "Monetary Intervention Mitigated Banking Panics during the Great Depression: Quasi-Experimental Evidence from a Federal Reserve District Border, 1929-1933.” Journal of Political Economy 117 (no. 6), December, pp. 1031-1073

Rockoff, Hugh (1974). “The Free Banking Era: A Reexamination.” Journal of Money, Credit and Banking 6, pp. 141-167.

Rolnick, Arthur and Warren Weber (1983). “New Evidence on the Free Banking Era.” American Economic Review 73 (no. 5), December, pp. 1080-1091.

Sayers, Richard (1957). Central Banking after Bagehot. Oxford: Clarendon Press.

Schwartz, Anna J. (1986). "Real and Psuedo-Financial Crises.” In F. Capie and G. E. Wood (eds.), Financial Crises and the World Banking System. London: Macmillan.

Silber, William (2007). When Washington Shut Down Wall Street: The Great Financial Crisis of 1914 and the Origins of America's Monetary Supremacy. Princeton: Princeton University Press.

Sprague, Oliver M. W. (1915). “The Crisis of 1914 in the United States.” American Economic Review 5 (no. 3), September, pp. 499-533.

Sprague, Oliver M.W. (1910). History of Crises Under the National Banking System. U.S. National Monetary Commission, Senate Document No. 538, 61 Cong. 2 Sess. Washington: Government Printing Office.

Taylor, John B. and John C. Williams (2009). “A Black Swan in the Money Market.” American Economic Journal: Macroeconomics 1 (no. 1), January, pp. 58-83.

Temin, Peter (1989). Lessons from the Great Depression. Cambridge, MA: MIT Press.

Temin, Peter (1969). The Jacksonian Economy. New York: W. W. Norton.

Timberlake, Richard (1993). Monetary Policy in the United States: an Intellectual and Institutional History. Chicago: University of Chicago Press.

Timberlake, Richard (1984). “The Central banking role of Clearing House Associations.” Journal of Money, Credit and Banking 16 (no. 1), February, pp 1-15. 
Warburg, Paul M. (1910a). The Discount System in Europe. National Monetary Commission. U.S. Senate Document no. 402. Washington, D.C.: U.S. Government Printing Office.

Warburg, Paul M. (1910b). “The United Reserve Bank Plan.” Chapter III in Paul Warburg, The Federal Reserve, Volume 1. New York: MacMillan.

West, Robert Craig (1977). Banking Reform and the Federal Reserve, 1863-1927. Ithaca: Cornell University Press.

Wheelock, David C. (2010). Lessons Learned? Comparing the Federal Reserve's Responses to the Crises of 1929-1933 and 2007-2009.” Federal Reserve Bank of St. Louis Review 92 (no. 2), March/April, pp. 89-107.

Wheelock, David C. (1992). "Seasonal Accommodation and the Financial Crises of the Great Depression: Did the Fed 'Furnish an Elastic Currency?'” Federal Reserve Bank of St. Louis Review 74, November/December, pp. 3-18.

Wheelock, David C. (1991). The Strategy and Consistency of Federal Reserve Monetary Policy, 1924-1933. New York: Cambridge University Press.

Wheelock, David C. (1990). "Member Bank Borrowing and the Fed's Contractionary Monetary Policy During the Great Depression." Journal of Money, Credit, and Banking 22 (no. 4), November, pp. 409-26.

White, Eugene N. (1983). The Regulation and Reform of the American Banking System. Princeton: Princeton University Press.

Wicker, Elmus (2005). The Great Debate on Banking Reform: Nelson Aldrich and the Origins of the Fed. Columbus: Ohio State University Press.

Wicker, Elmus (1966). Federal Reserve Monetary Policy 1917-1933. New York: Random House, 1966. 


\section{Appendix}

\section{Legislated Changes to the Federal Reserve's Lending Authority ${ }^{28}$}

December 1913: The Federal Reserve Act is signed into law. The Act authorizes Federal Reserve Banks to rediscount eligible paper for member commercial banks.

September 1916: An amendment to the Federal Reserve Act adds Section 13(8), which authorizes Federal Reserve Banks to make advances to member banks on their own notes secured by paper eligible for discount or purchase or by the "deposit or pledge of bonds or notes of the United States."

February 1932: The Glass-Steagall Act amends the Federal Reserve Act by permitting U.S. Government securities to serve as collateral for Federal Reserve notes. The Act also adds Section 10(a), which permits Federal Reserve Banks to lend to groups of five or more member banks, and Section 10(b)), which permits Federal Reserve Banks to lend to any member bank with capital not exceeding $\$ 5$ million on the basis of any satisfactory assets, whether or not technically eligible for rediscount, in exceptional and exigent circumstances. The provision stipulates that any such loans require the approval of at least five members of the Federal Reserve Board and shall bear an interest rate not less than 1 percent above the regular discount rate. Sections 10(a) and 10(b) are set to expire in March 1933.

July 1932: The Emergency Relief and Construction Act adds Section 13(3) to the Federal Reserve Act permitting the Reserve Banks to lend in unusual and exigent circumstances and with the authority of the Federal Reserve Board, to any individual, partnership, or corporation unable to secure adequate credit accommodations from other banking institutions. Section 13(3) loans must be secured by paper "of the kinds and maturities eligible for discount for member banks under other provisions" of the Federal Reserve Act and carry the endorsement of the borrower or a third-party surety.

March 1933: The Emergency Banking Act extends Section 10(b) until March 1934, and eliminates the provisions that restrict Section 10(b) loans to banks with capital not exceeding \$5 million and require the approval of at least five members of the Federal Reserve Board. The Act also adds Section 13(13) to the Federal Reserve Act authorizing Federal Reserve advances to any individual, partnership or corporation for periods of not more than 90 days on notes secured by direct obligations of the United States or issued or fully guaranteed by U.S. agencies. A subsequent amendment to the Emergency Banking Act authorizes for a period of one year Federal Reserve loans to nonmember banks in limited circumstances on the same terms as advances to member banks under Section 10(b). This authority expired in March 1934 and was not renewed.

June 1934: The Federal Reserve Act is amended by adding Section 13(b), which authorizes Federal Reserve Banks to make working capital loans to businesses. Section 13(b) was repealed under the Small Business Investment Company Act of 1958 [Hackley, 1973, p. 135, p. 145]

\footnotetext{
${ }^{28}$ A compilation of textual changes in the Federal Reserve Act is available from the Board of Governors of the Federal Reserve System (http://fedweb.frb.gov/fedweb/board/legal/lawlib/textual-FRA.htm).
} 
August 1935: The Banking Act of 1935 makes permanent Sections 10(b) and 13(3) of the Federal Reserve Act. The Act removes the requirement that discount loans under Section 10(b) be made only under "exceptional and exigent circumstances." It also eliminates a provision of Section 13(3) requiring that loans to individuals, partnerships or corporations be secured by both collateral eligible for discount by member banks and the endorsement of the borrower or a thirdparty surety.

March 1980: The Monetary Control Act of 1980 subjects most depository institutions to reserve requirements and provides that any depository institution that holds transactions accounts or nonpersonal time deposits subject to Federal Reserve requirements shall be entitled to the same discount and borrowing privileges as Federal Reserve member banks.

December 1991: The Federal Deposit Insurance Corporation Improvement Act of 1991 amends Section 13(3) of the Federal Reserve Act by deleting the requirement that Federal Reserve loans to individuals, partnerships or corporations be secured by collateral "of the kinds and maturities made eligible for discount for member banks." The Act also subjects the Federal Reserve to a potential liability to the FDIC on discount window loans to undercapitalized or critically undercapitalized depository institutions.

July 2010: The Dodd-Frank Wall Street Reform and Consumer Protection Act of 2010 amends the Federal Reserve Act to permit only "broad-based” liquidity facilities under Section 13(3) and requires approval of the Secretary of the Treasury for any facilities established under Section 13(3). Further, the Federal Reserve must disclose the identities of borrowers under any 13(3) facilities within one year after the termination of the facility. The legislation also requires the Federal Reserve to disclose the identities of all discount window borrowers after a two year delay. 


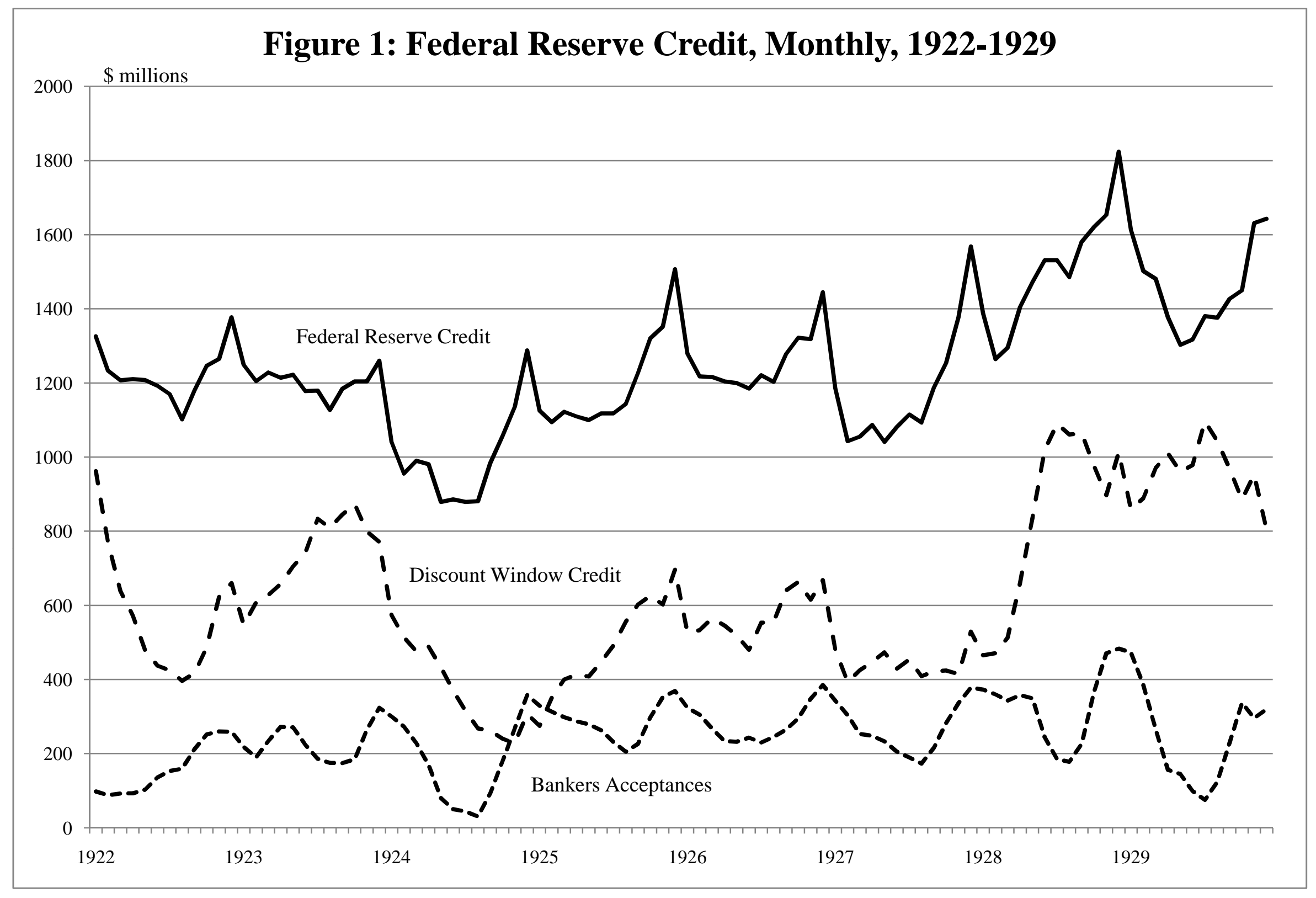




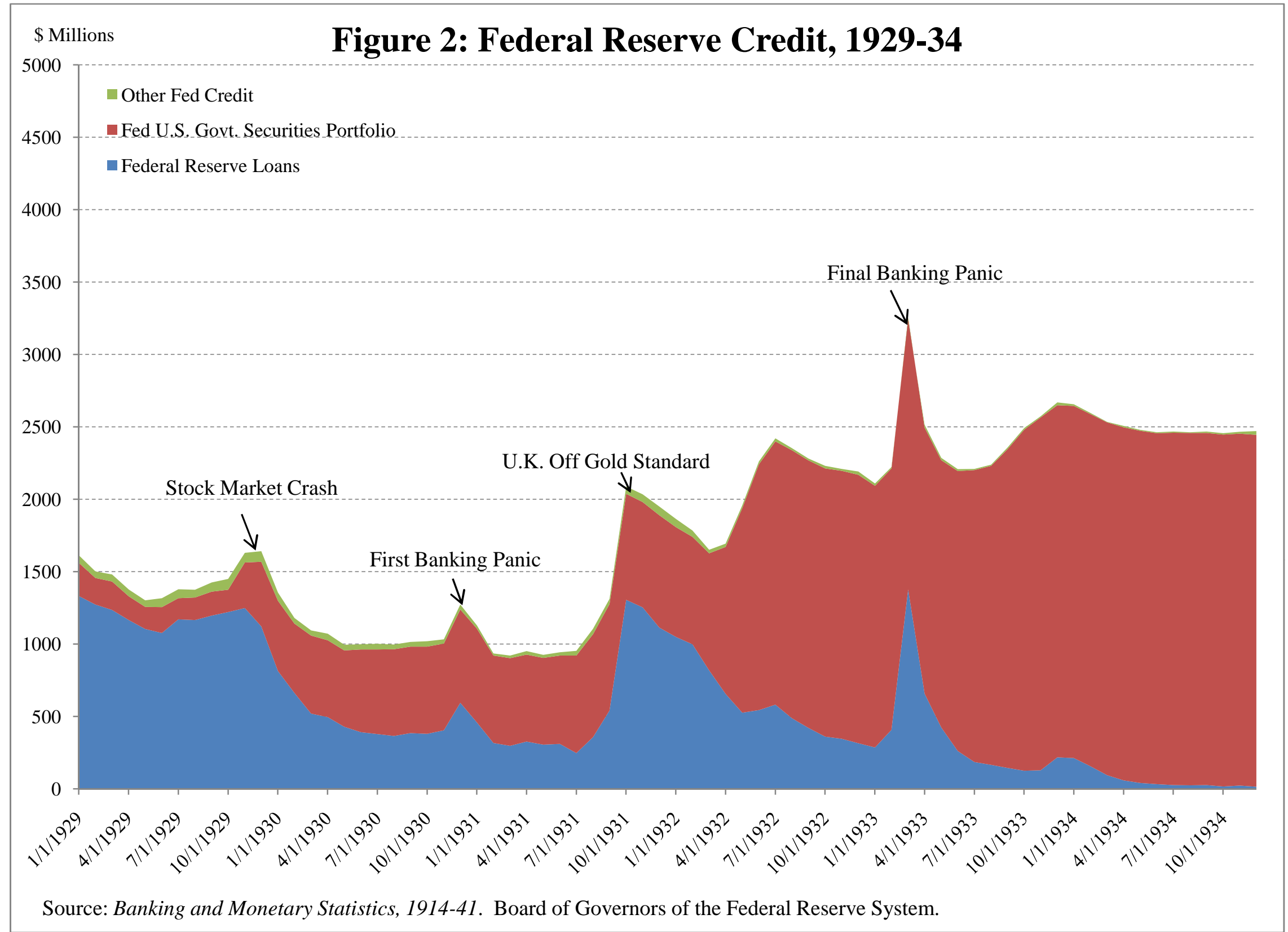




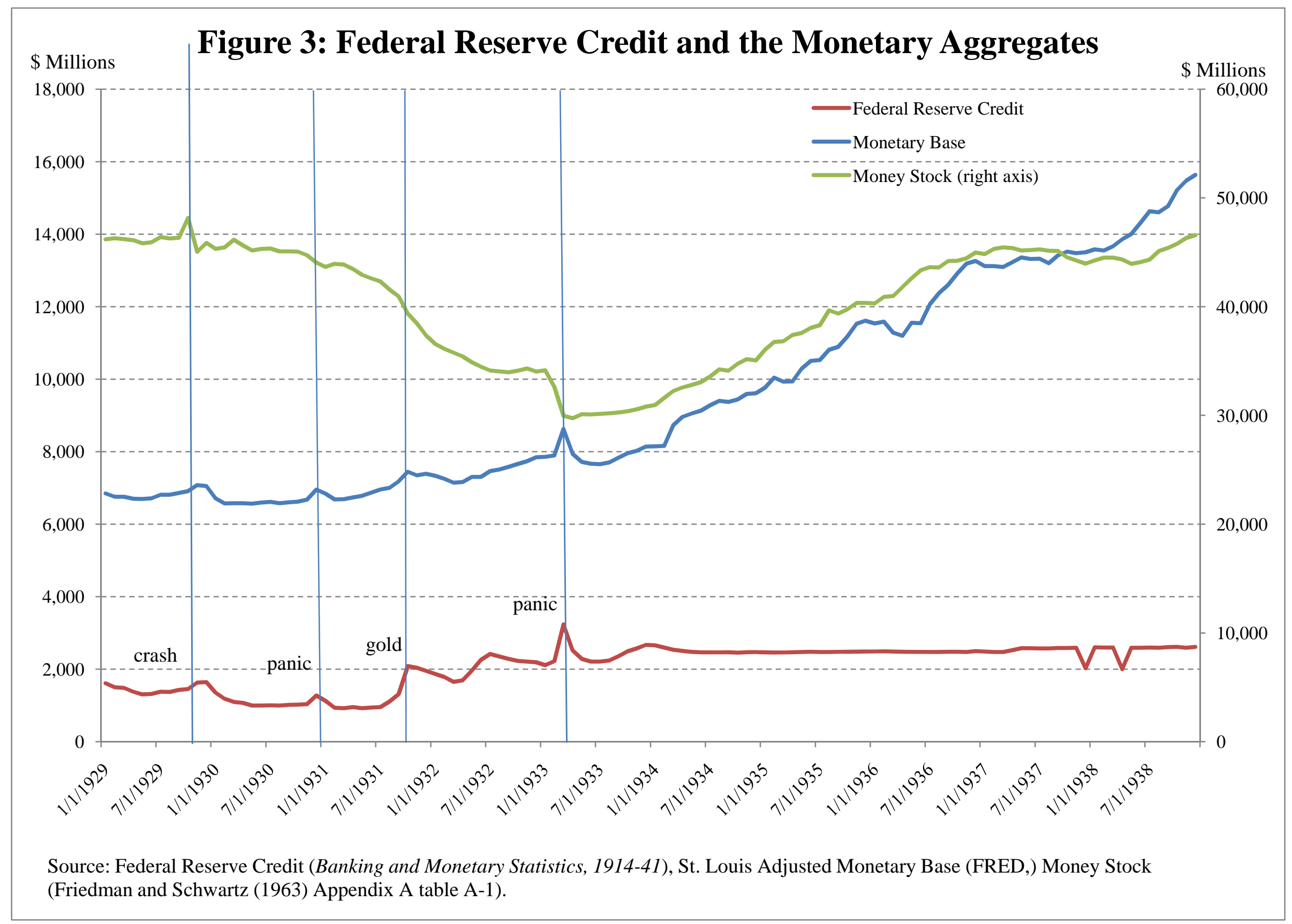

